European journal of American studies

Summer 2017, including Special Issue: Popularizing

Politics: The 2016 U.S. Presidential Election

\title{
"Who Can Estimate the Value of a Book!": Buying and Owning Books in Antebellum Domestic Fiction
}

Johanna McElwee

\section{OpenEdition}

\section{Journals}

Electronic version

URL: https://journals.openedition.org/ejas/12015

DOI: $10.4000 /$ ejas. 12015

ISSN: 1991-9336

Publisher

European Association for American Studies

Electronic reference

Johanna McElwee, "'Who Can Estimate the Value of a Book!": Buying and Owning Books in Antebellum Domestic Fiction", European journal of American studies [Online], 12-2 | 2017, document 2, Online since 01 August 2017, connection on 09 July 2021. URL: http://journals.openedition.org/ejas/12015 ; DOI: https://doi.org/10.4000/ejas.12015

This text was automatically generated on 9 July 2021.

Creative Commons License 


\title{
"Who Can Estimate the Value of a Book!": Buying and Owning Books in Antebellum Domestic Fiction
}

\author{
Johanna McElwee
}

\begin{abstract}
Instead of twenty-five dollars' worth of glass and gilding, we have some of the best productions of the best minds. Instead of a poor gratification of our vanity, or at best of our eyes, we have a productive capital, from which we may derive exhaustless pleasure, which hundreds may share, and which those who come after us may enjoy. $\mathrm{O}$, who can estimate the value of a book!

Catharine Maria Sedgwick, Home (14)
\end{abstract}

When Mr. Barclay, in Catharine Maria Sedgwick's novel Home (1835), marries his wife, his father-in-law gives him some money to help them establish their new home. The father-in-law also gives him advice on how the money should be spent, but Mr. Barclay rejects his advice and instead of buying showy furniture, he buys books, claiming that they are "essential to happiness" (11) and that their new home will never be a happy one without the presence of "a book-case filled with well selected and well bound volumes" (11-12). Thus, when Mr. Barclay also exclaims "O, who can estimate the value of a book!" (14), this may seem to be a purely rhetorical question whose obvious answer is that books are priceless; they are not to be valued in terms of money. However, Mr. Barclay also discusses books as an "investment," and "stock" (13), which, together with the fact that he is a printer whose livelihood depends on people's willingness to buy books and other printed matter, suggest that his question is not merely a rhetorical one. What, indeed, is the value of a book? The present paper will explore this question and the role of books in antebellum domestic fiction, focusing especially on Sedgwick's Home, Eliza Leslie's Mr. and Mrs. Woodbridge: A Story of Domestic Life (1841), and Susan Warner's The Wide, Wide World (1850) and it will show the importance of owning books, not just reading them, to the antebellum middle-class citizen. ${ }^{i}$ Tracing the presence of books in domestic narratives, this paper will argue that books place the protagonists securely in the middle class regardless of their economic situation, which suggests that 
middle-class status is a matter of inclination and individual character, rather than economy.

My effort to trace the presence of books in domestic fiction is inspired by the suggestive proposition made by Catherine Gallagher and Stephen Greenblatt in Practicing New Historicism where they describe a common new historicist strategy as "pick[ing] up a tangential fact and watch[ing] its circulation" (4). In a similar manner, this paper seeks to follow the book to see where it appears and is absent in nineteenthcentury domestic fiction. As material possessions came to signify, establish, and contest class affiliation in the nineteenth century, the tracing of individual objects, especially those with symbolic value, such as the book, can provide further insight into the process through which middle-class values came to transcend class boundaries and become normative. As we will see, in domestic fiction, the ownership of books is a litmus test for class affiliation.

\section{Classifying Books}

3 Between 1790 and 1870, the U.S. went through fourteen economic depressions, with one of the severest so-called "panics" occurring in 1837 (Fichtelberg 11). The middle class, Mary Templin maintains, was especially hard hit by the fluctuations in the national economy (68). In fact, as Joseph Fichtelberg points out, market panic could even be considered a "spur to middle-class consciousness" as it encouraged new attitudes to work and economy that were better adapted to the volatile economic situation (202). Another catalyst for the emerging middle class was the changing of the occupational map. Stuart Blumin notes that in the nineteenth century, manual and non-manual jobs became increasingly separated, both in terms of space and class (68). By the 1820 s, occupations in urban areas of the country were becoming increasingly specialized (93) and work that had previously been performed in the homes of the middling classes was moved to workplaces outside the home, leaving the home a purely domestic space (155). In her study of Oneida County, New York, Mary Ryan shows that the separation of the home and the workplace paved the way for the ideal of domesticity, which became the heart of middle-class ideology.

Blumin contends that the middle class developed into a relatively distinct group in the middle decades of the nineteenth century (12), which Templin confirms as she observes that social boundaries were quite stable by the 1830 s and there was little movement between the uppermost layers and those at the bottom at this time (67). However, despite limited opportunities for social ascension, Templin argues, "social mobility remained a commonly held assumption and a source of considerable anxiety as well as hope" (68) and she claims that the middle class "was the site of the greatest uncertainty regarding social and economic status" (68). ${ }^{\text {ii }}$

Emerging in tandem with middle-class consciousness, the domestic novel became a mouthpiece for the ideal of domesticity, where the home and the family were posited as central units for the promulgation of values seen as necessary for the stability of the nation. In domestic narratives, which in some cases can be read as manuals, the challenges of creating and maintaining a successful middle-class home are explored through discussions of proper childrearing, the proper care of a husband and, also, how to furnish a home and dress properly. Through their focus on the interior decoration of a home and the possessions of its inhabitants, domestic narratives can, in fact, be read 
as shopping guides and the intended shoppers are primarily the women of the household since the responsibility of creating and maintaining a home largely fell on them. iii

6 One of the most popular domestic novels of its time, Sedgwick's Home offers readers a guide in how to achieve domestic perfection. Praising its didactic character, a contemporary critic claimed that "no one can read [Home] without catching some good influences" (qtd. in Damon-Bach, Clements 171). iv The novel depicts Mr. and Mrs. Barclay from the early days of their marriage, as their children grow up and until the family moves from the city and retires on a farm. Portraying a model middle-class family, the novel gives advice on how to develop proper middle-class values and habits and how to raise virtuous and refined children. Early in the novel, the Barclay home is described through an inventory of its contents, detailing

ample stores of household linen, fine mattresses, as fine an apparatus for ablutions as a disciple of Combe could wish; jugs, basins, and tubs large enough, if not to silence, to drown a travelling Englishman; and finally one luxury, which long habit and well cultivated taste had rendered essential to happiness-a book-case filled with well selected and well bound volumes. (11-12)

Through this description, readers are provided with a model for interior decoration and instructions on what to acquire for their homes. Surrounded by their possessions, Mr. and Mrs. Barclay establish and raise their family. ${ }^{\mathrm{v}}$

Home not only lists items desirable for purchase; it also offers guidance on what to avoid in a model home: the Barclays reject "mantel glass, ornamented lamp[s], vase[s] of Paris flowers, [and] tawdry pictures" (11), as these are items that will not add to the refinement of their home. Richard L. Bushman sees refinement as one of the foremost qualities signifying middle-class status in the antebellum period. Up until the late eighteenth century, the ideal of refinement, which involved the building of stylish homes and the adoption of certain styles of speech, dress, and behavior, was limited to the privileged classes (xii). However, the ideal spread to the middling classes of society and by the mid-nineteenth century, "[a]ll who aspired to simple respectability had to embody the marks of the genteel style in their persons and their houses" (xiii).

Refinement was expressed through owning the right items and displaying the right manners. At the same time, because of its roots in aristocratic Europe, refinement was a problematic ideal to emulate in post-Revolutionary America as it clashed with republican values like frugalness and simplicity. According to Bushman, this paradox is played out in sentimental fiction, which he argues domesticates refinement by "transplant[ing it] from balls and assemblies... to homes" (281), this way making it an acceptable ideal for Americans to strive for.

Despite having been domesticated, refinement required a host of items previously found primarily in aristocratic homes. Templin notes that possessions that were either unavailable or unusable by the working class, such as books or musical instruments, singled their owners out as middle-class (88). In order to be perceived as refined, people from the eighteenth century and onwards bought carpets, mahogany furniture, candlesticks-and books (Bushman xvii). Bushman shows that books were privileged among the items necessary for refinement. In fact, "[n]o single item was more essential to a respectable household than a collection of books" (282).

In domestic tales, the appreciation and possession of books are not only a sign of middle-class status, but also of a character's moral worthiness and refined character- 
qualities that are, it is suggested, endemic to the middle class. A protagonist who is not a book-lover is all but inconceivable in these narratives. Illustrating this point, Sedgwick's novel The Poor Rich Man and the Rich Poor Man (1836) suggests that loving books is a prerequisite for moral virtue and personal happiness. A discussion early in the narrative among some children about the book prizes they have won in school reveals what the future will hold for them. ${ }^{\text {vi }}$ Upon receiving her prize, Paulina goes straight to Hutchinson's store and exchanges it for a pink silk handkerchief. Her classmate Morris is happy that he got a book which he expects will yield a high price when he sells it, saying that "[m]oney should work" and he scoffingly tells another of the children, Susan, that "I guess you would not like to have your money lying idle on a book-shelf" (13), when she objects to his valuing books solely in terms of money. Morris also happily notes that his book "cost twice as much as [their friend Harry's] Bible" (13). Later in life, Paulina ends up an opium-addicted adulteress, and Morris makes a fortune on speculations, marries a fashionable and shallow woman, and leads a loveless life, burdened by financial worries as his wife spends their money uncontrollably. Harry, on the other hand, marries his childhood sweetheart Susan and finds himself a poor, but happy husband and father, surrounded by a loving family. One of the treasures of the family is a shelf of books, which they share freely with their neighbors, thus contributing to the moral and intellectual improvement of the whole community. Through their appreciation of books, Harry and his family posit themselves as middle class, despite their apparent lack of economic assets. As Amal Amireh points out, "in their contentment and in their possession of certain manners and virtues... [Harry's family is] an example of a poor family with middle-class values" (55). Unlike Paulina and Morris, who treat their book prizes solely as commodities whose value lies in their commercial potential, Harry sees other, non-monetary values in the book. In the end, only the book-lover leads a happy, virtuous, and middle-class life. Serving as an instrument of classification, books, Sedgwick implies, and attitudes to books give an indication of the future lives of individuals, in terms of moral character, happiness, and, also, social class. vii

\section{Buying Books}

While the children who treat books solely as commodities lead unhappy lives, The Poor Rich Man and the Rich Poor Man also suggests that some acknowledgement of the commercial potential of books should be made. Ironically enough, despite his initial refusal to sell his book prize, Harry, too, ends up a seller of books. When Susan's sister falls dangerously ill, Harry decides to give up his plans of going to school and instead becomes a book peddler to help pay for the doctor. In other words, although Harry, like other protagonists of domestic fiction, values books primarily for their moral and aesthetic qualities, he does not hesitate to exchange a book for money when the situation demands it. Mr. Barclay in Home presents a similar attitude to books. In the early days of their marriage, Mr. Barclay tells his wife how he has "made a yearly investment in books, as the stock which would yield the best income" and bought books which he hopes will "profit" them both (13) and he describes the books as "a productive capital" (14). Even though the Barclays mainly value books for their moral, aesthetic and educational qualities, Mr. Barclay's choice of words reveals that books belong to the world of commerce, even if they also serve what is perceived to be a higher end. The fact that Mr. Barclay is a printer, whose professional success depends 
on the commercial value of printed material, including books, also indicates that books are commodities. For the Barclays, then, books are an investment in a prosperous future, both through their own purchases and through the selling of books.

Susan Warner's The Wide, Wide World provides another example of the commodification of books as it shows that even the Book of Books, the Bible, is a commercial product, whose worth is based not only on its content and symbolic significance, but also on its appearance. The novel portrays eleven-year-old Ellen Montgomery as she is forced to leave her parents and move to her Aunt Fortune's farm. Struggling to cope with her aunt's strict rules and unloving manner, she finds solace in her books, her religion, and in the company of her neighbors, the refined-and middle-class-Humphrey family. In preparation for Ellen's journey to her aunt, her mother takes her shopping to fit her out for her new life. The novel depicts Ellen's very first decision as a consumer: the purchase of a Bible. In order to buy her daughter this gift, Mrs. Montgomery has to sell a ring left to her by her mother, which emphasizes the Bible's commercial value. viii Having secured the money, she takes Ellen to a shop with a large selection of Bibles and asks her to choose one. Overcome by the moment, Ellen enters into a state of frenzy which Gillian Silverman refers to as "Bible lust" $(140)^{\text {ix: }}$

Ellen's wits were ready to forsake her. Such beautiful Bibles she had never seen; she pored in ecstasy over their varieties in type and binding, and was very evidently in love with them all.

...with flushed cheek and sparkling eye, and a brow grave with unusual care, as though a nation's fate were deciding, she was weighing the comparative advantages of large, small, and middle-sized; black, blue, purple, and red; gilt and not gilt; clasp and no clasp. (29-30)

The Holy Book is no less a commodity, offered in different colors, sizes and price ranges, than a pen or a plate-glass lamp. Nevertheless, just as in Home and The Poor Rich Man, it is suggested that books carry values beyond those of commerce. Ellen's new Bible is expected to improve her moral character as well as help establish other personal qualities associated with middle-class femininity-and, yes, since the stability of the republic was felt to depend on the virtue of its citizens, this purchase might even affect the "nation's fate."

Books, then, are measured according to two, sometimes conflicting value systems. Whereas books can be purchased and put on a shelf to signify and achieve middle-class status, in domestic tales this is not enough. Books and other consumer goods should also be cherished, since this will transform them from commodities into beloved possessions. ${ }^{\mathrm{xi}}$ Challenging the commonly held view among historians where the home and the market are posed as opposites, Lori Merish contends that the domestic space, in fact, was dependent on the market since the consumer goods that constituted a necessary ingredient in the ideal of domesticity were also market commodities. At the same time, however, it was necessary to separate oneself from the market world in order to be able to cultivate those moral and aesthetic qualities necessary for middleclass status. Merish finds that the logic in domestic fiction seems to be that "it's fine to shop and buy things; but once at home, be sure to take the price-tag off" (Sentimental Materialism 134). Thus, Mr. Barclay's seemingly rhetorical question is highly pertinent. Who, indeed, can estimate the value of a book? Or, rather, how should the value of a book be estimated?

16 The financial investments of Mr. Barclay provide an answer to these questions. Rather than speculating in stocks or land (activities that are universally condemned in 
domestic fiction), Mr. Barclay has put his capital into books, an investment that, considering the volatile national economy, turns out to be a wise one. Although their books are described as the "one luxury" (11), the Barclays consider books to be an absolute necessity in their home and, as a result, they choose to buy books rather than other consumer goods. Confirming the wisdom of the Barclay's shopping preferences, Lydia Maria Child writes in her advice book The Mother's Book: "I am aware that all cannot afford to buy books freely; but I believe there are very few in this land of abundance, who do no spend in the superfluities of dress and the table, more than enough to purchase a valuable library" (87-88). By implying that the purchase of books is a matter of choice and not restricted to the wealthy, both Home and The Mother's Book portray the buying of books - not just reading them- as a duty for all who aspire not only to middle-class status, but to domestic felicity. Books might be bought for money, but their value, it is suggested, goes beyond the market.

Representing a contrast in Home, Mr. Barclay's business partner, Mr. Norton and his family show the consequences of making the wrong investments. Unlike the Barclays, who choose books over gaudy furniture, the Nortons live in a mansion filled with elegant furniture and give lavish parties. They strive to establish themselves in the fashionable circles of society and spend money on showing off rather than on that which will promote a happy and comfortable domestic environment. It all comes to an end when Mr. Norton's son becomes involved in "that species of gaming called speculation" (121), xii puts the family in debt and then kills himself. Being on the brink of destitution, Mr. Norton suddenly dies, leaving his family at the mercy of their neighbors. Books and reading are not valued in the Norton family and, as their social position is based solely on their fortune, their social descent is dramatic when they lose their wealth. Since they are business partners, Mr. Barclay also loses money in this affair and it has severe economic consequences for the family as they are forced to postpone their long-cherished plan of moving to a farm in the countryside. However, the Barclays retain their domestic stability and happiness and also their middle-class status as their class identity is not based on money, but on values and manners created in the home and with the help of books. In their choice of furniture and lifestyle, Mr. Norton and Mr. Barclay employ different strategies of consumption and, thereby, different strategies for establishing social position. Whereas Mr. Barclay makes good consumer choices, which establish him as a refined member of the middle-class, $\mathrm{Mr}$. Norton's choices (or, rather, his failure to control the consumption of his son and daughter-in-law) are the reason for his and his family's moral degeneracy and fall from fortune and also explain their lack of refinement. By presenting middle-class status as a matter of consumption, where certain commodities help bolster the effects of economic loss, while the purchase of the wrong commodities leads to ruin, Home seemingly offers a strategy for those wishing to become socially and economically, as well as morally, solvent.

Eliza Leslie's novella Mr. and Mrs. Woodbridge presents another example of the consequences of faulty habits of consumption, thus providing advice on how to stay clear of the pitfalls in the world of commerce. Here, too, we follow a newlywed couple as they establish their first home. Unfortunately, influenced by the bad example of her mother, Charlotte Woodbridge has not learned the proper manner of consumption and this has severe consequences for her husband's health and career, for the young couple's financial situation, and for their relationship. Charlotte is guided by a wish to show off when furnishing and decorating her new home and she finds "Saxony carpets, 
and silk curtains, and silk-covered lounges, and large glasses, and chandeliers, and beautiful mantel-lamps; and, above all... elegant things for the centre-table" (123-124) to be indispensable in her new home. However, when her husband, Mr. Woodbridge, reveals his intention of turning a room into a library, "fitted up with bookshelves, and furnished with a library-table, a stuffed leather fauteuil, a reading lamp, and whatever else is necessary to make it comfortable" (121), Charlotte objects since she wants this small backroom for a sitting- and dining room for the two of them. The parlors, then, are not to be used for other purposes than to present a fashionable façade. Charlotte spends lavishly on furniture, but she is very stingy in her housekeeping (which is one of the reasons why she wants the small room in the back for a dining room, so that visitors will not catch them at their scanty meals), with the result that her husband finds a comfortless, often dark, house at the return home after a long day at the office. Apart from showy furniture, clothes are the only items Charlotte wants to spend money on and "[a] book was one of the last things she would have thought of purchasing for herself; and she even looked displeased whenever her husband bought a new one for his own reading; and wondered what people that had the Athenaeum to go to, and also a share in the City Library, could possibly want with any more books" (141). Driven away by the lack of comfort at home, Mr. Woodbridge starts taking his meals at restaurants instead and Charlotte's unwise and costly purchases threaten to ruin the family. Fortunately, after a visit from Charlotte's deeply unhappy father, who has become a drunkard because her mother acted in the same manner as Charlotte, Charlotte is reformed, and one of her first steps toward becoming a better wife and housekeeper is to suggest that her husband turn the combined sitting- and dining room into a library, which he promptly does. Replacing her desire for dresses and silk curtains with a wish to create a comfortable home for her husband, Charlotte becomes a good consumer, as well as a good wife, as she learns to crave the right possessionsthose that promote domestic happiness. With the creation of a library and a bigger piece of the household budget spent on food, Mr. Woodbridge comes home in the evenings and domestic stability is established, which means that the couple's position on the social ladder is secured. Echoing the words of Mr. Barclay in Home, for the Woodbridges, books are an "investment" (13) and a "productive capital" (14). In the end, Charlotte even develops "a taste for books" (187).

In Mr. and Mrs. Woodbridge, the wife's skills of consumption determine the moral, economic, intellectual and, as a result, social status of her family. Home makes a similar suggestion as it is hinted that Mr. Norton's daughter-in-law played a significant role in the family's downfall because of her love of fashion and luxury. According to Mary Beth Sievens, the emergence of female consumption in post-Revolutionary America was perceived to be a threat not only to male authority, but also to the survival of the Republic (354). Sievens finds that although the tensions that arose between different groups in society due to the emergence of capitalism have received scholarly attention, the conflicts this economic transition created within families have not been much studied since families tend to be viewed as one economic unit (358-359). In both Mr. and Mrs. Woodbridge and Home, men are the victims of deficient skills of consumption among the female members of their households, which suggests the necessity of teaching women these skills. 
In her widely rad A Treatise on Domestic Economy (1841), Beecher argues that young Ther widely read A Treatise on Domestic Economy (1841), Beecher argues that young women should learn to handle their own expenses, asking

How else are young ladies to learn properly to make purchases, and to be systematic and economical? The art of system and economy can no more come by intuition, than the art of watchmaking or bookkeeping; and how strange it appears, that so many young ladies take charge of a husband's establishment, without having had either instruction or experience in the leading duty of their station! (179)

$$
\text { charge" without having been taught how "to make purchases." }
$$

Beecher suggests that young women should learn skills of consumption "under the guidance of her mother or some other friend" (178) and the case of Charlotte Woodbridge also indicates that the responsibility for this education primarily falls on the mother. The before-mentioned scene in The Wide, Wide World, where Ellen buys a Bible, presents another example of the role of mothers in teaching proper habits of consumption. Taking her daughter shopping is one of Ellen's mother's last acts of parenting, since she is fatally ill. Cautioning her daughter that "a great deal of skill and experience is necessary for a shopper, and what would you do without either?" (44), Mrs. Montgomery knows that the art of shopping is a vital skill for a young woman to master. While letting Ellen pick out her own Bible, her mother gently guides her towards a sensible and practical choice and this way ensures that she makes a good consumer decision. This purchase is the first step in Ellen's education toward becoming a skilled consumer, and, thus, a middle-class lady. Through the guidance of her mother, Ellen will avoid the consumer mistakes made by Charlotte in Mr. and Mrs. Woodbridge.

\section{Owning Books}

In Home, Mr. and Mrs. Woodbridge, as well as The Wide, Wide World, class position is demonstrated through not only the purchase, but also the display of consumer goods. When Ellen first enters her aunt Fortune's house, she is horrified by its lack of refinement. Not only does the home lack carpets and soft sofas. If one wants to wash up, one must go outside to the spout (remember the apparatus for ablutions in the Barclay home) and, most shockingly, there are no books, not even the Bible. Aunt Fortune's rejection of books is a choice of consumption as well as a rejection of middleclass values. Although she is respectable in the sense that she is hard-working and keeps a well-ordered household, Aunt Fortune is also hard-hearted, bad-tempered, and cares nothing for religion. Consequently, she does not assume the behavior and values expected in a middle-class woman-those of virtuous, Christian femininity-which are what female protagonists in these narratives are expected to strive for. Instead, as her name indicates, Aunt Fortune is all about the money, which is not conducive to a feminine middle-class identity.

24 Aunt Fortune and her bare and bookless home are contrasted with her neighbors, the Humphreys, and their beautiful and inviting home. On Ellen's first visit to the Humphreys, the daughter of the family, Alice, shows her around in the home, which has comfortable furniture, flowers, and books. "[H]ere, Ellen," Alice says, "on this side between the windows, is my greatest treasure-my precious books. All these are mine" 
(164). While Aunt Fortune finds her treasure in livestock and land, Alice finds hers in books. Alice not only reads books, she owns them and she takes pleasure in owning them. Even though ownership is important to both Alice and Aunt Fortune, their different "treasures" signal that they belong to different social classes. ${ }^{\text {xiv }}$ Susannah Ashworth finds that through the contrast between Alice and Aunt Fortune, "reading becomes a resolutely white, middle-class activity, and by extension it becomes a very visible way to mark class identity" (151). The economic resources of Alice and Aunt Fortune are not the basis for their class affiliation-the fact that Aunt Fortune might very well be richer than the Humphreys is of no consequence-it is their differing attitudes to reading and books that determine where they belong on the social ladder. Also, it is her love of reading and books that enables Ellen to retain her middle-class identity while living with Aunt Fortune.

When Alice displays her books to Ellen, her pride suggests that the ownership of books is important in itself, not just for the opportunities of reading it offers. ${ }^{\mathrm{xv}}$ Assuming the values expected in a middle-class lady, Ellen, too, treasures the owning of books. At critical junctures in Ellen's life, she is given books and these books are decisive in her development into a refined middle-class lady. As we have seen, when Ellen is to be separated from her mother and sent to her Aunt Fortune's, her mother buys her a Bible, a book which acts as a companion and support during her hardships. On the boat taking her to her aunt, as she hides crying, an elderly gentleman, Mr. Marshman, gives her a book of hymns, kindly marking some of the hymns for her to read and contemplate especially (78). In addition, as Ellen becomes established in the home of Aunt Fortune's neighbors, the Humphreys, John Humphrey gives her Parson Weem's Life of Washington, a gift that means a great deal to Ellen both for its content and as a physical object: "the book was in her head all the while.... Even when she went to be dressed her book went with her, and was laid on the bed within sight" (330). Later on, when Ellen is about to leave for Scotland and her mother's family there, John gives her the copy of Pilgrim's Progress that the two of them have been reading together. The fact that Ellen is given books at important turning points in her life not only suggests the shaping power books were felt to have, it also shows the importance of owning books. ${ }^{\mathrm{xi}}$ Moreover, Ellen's accumulating library further distances her from her aunt and reveals that she is more closely related in spirit-and class-to the Humphreys, into whose refined and comfortable home she eventually moves, a move that indicates that class affiliation outweighs blood ties.

The presence of books is important in the Humphrey home, not only to signal class affiliation and refinement, but also because books-together with the sofa, carpet, and flowers-make that home comfortable, which is another necessary quality of the middle-class home. In her study of middle-class parlors in Victorian America, Katherine C. Grier presents "culture" and "comfort" as two key terms defining prevailing ideals at the time, where "culture" signifies the wish to create a façade and show off, while "comfort" represents the ideal of domesticity, where the home and the family is at the center. According to Grier, some contemporary social commentators saw "comfort" as "a distinctly middle-class state of mind" (2) and she suggests that "comfort" offered a solution to the dilemma of how to reconcile aristocratic traditions with republican ideals (viii). xvii Comfort was established through material means and, as John Crowley shows, the ideal of comfort emerged together with the development of consumer society in Britain and America, since the increasing availability of comfort to a greater segment of society also meant a greater need for items felt necessary to create this 
quality (142-143). In Warner's novel, "comfort" is used to contrast the home of Aunt Fortune from those of the Humphreys and another family, the Marshmans. When Ellen enters her new room at her Aunt's, she is appalled by the lack of furniture and bare floor, which "to Ellen [looked] very comfortless" (102). This room is the opposite of a room she is to inhabit later, as she visits the refined and affluent Marshman family, which is "the very picture of comfort" (287) (and which incidentally contains a bookcase). Aunt Fortune, who is engaged in a never-ending round of household chores, keeps a spotless house, but it does not seem like a home as it is not (nor does it aspire to be) comfortable. In the beginning of Leslie's novella, lack of comfort is the pervading quality of the Woodbridges' home and it is this lack that drives away Mr. Woodbridge. When Mr. Woodbridge suggests that the backroom in their new house be turned into a library, he seeks to establish a comfortable space, which his wife considers unnecessary since she values showiness over comfort. Also in Home, when Mr. Barclay explains to his wife how he went about purchasing items for their home, "comfort" is a key word. While in showy houses there may be found the before-mentioned "mantel glass, ornamented lamp[s], vase[s] of Paris flowers, [and] tawdry pictures," these homes often show a "lamentable deficiency of substantial comforts" (11), Mr. Barclay claims. The Barclay home, on the other hand, contains items promoting comfort, such as "fine mattresses... an apparatus for ablutions... and... a book-case" (11). Thus, whereas at Aunt Fortune's, one is forced to wash outside at the spout and can find nothing to read, the Barclay home provides opportunities both for washing and reading-activities that promote comfort. In the home of Mr. and Mrs. Woodbridge, showiness is eventually replaced by a more comfortable arrangement, which leads to a happy home and a blissful marriage.

As the case of the Woodbridges shows, creating a comfortable home has implications beyond those of social position; it is also necessary for conjugal happiness. Also, personal comfort was considered a prerequisite for a charitable character. Merish points out that when freed from bodily discomfort, the individual was able to care for others and, as a result, discomfort was morally dangerous as it might make a person insensible and less charitable (Sentimental Materialism 122-123). In a similar vein, Grier notes that by the 1830s, the notion of "domestic environmentalism" took hold, according to which the house itself could affect one's character, this way suggesting that, "moral guidance [was conflated] with the actual appearance and physical layout of the house and its contents" (6). In other words, the reason for the hard-heartedness of Aunt Fortune might be her choice of interior decoration and the floor plan of her house. Being comfortable oneself, one was able to promote the comfort and well-being of others as well, which meant that society as a whole benefitted from comfortable homes.

The comfort provided by the presence of books and other refined objects also had other social and personal benefits. Discussing frontier narratives, Merish shows that consumer goods felt to promote comfort could have a civilizing effect, as well as establish and protect the religious and moral character of their owners ("'The Hand of Refined Taste" 487). Although The Wide, Wide World is hardly a frontier narrative, Ellen's move to her aunt's is still portrayed as a move away from civilization, since Aunt Fortune's farm lacks many of the physical and intellectual comforts Ellen has taken for granted in her urban home. For Ellen, objects signifying refinement and comfort, such as a writing desk and books, serve to keep her "civilized" and a devoted Christian despite the culturally impoverished environment at her Aunt Fortune's. The choice of a 
Bible which is of a size that makes it easy to read in but also to carry around-a comfortable size-is just one item that will keep her on the right path. Similarly, when the eldest son in Home, Charles, goes West, his father gives him books to bring with him. Charles turns one of the two rooms in his house into a reading room and, having "literally made a circulating library of the books [his] father gave [him]" (209), invites all the men in the settlement to make use of this room and the books in it. Together they also subscribe to some periodicals that they keep in the reading room and they meet regularly to exchange ideas about what they read. By making his books available to his neighbors, Charles takes on the role of a missionary spreading the ideals of refinement, but also the word of God since the room is also used for religious meetings. Merish notes that, by the 1830s, "luxury and tasteful surroundings" were felt to have a "ccivilizing" effect, especially regarding domestic surroundings which the individual had the most control over and was most often exposed to (Sentimental Materialism 91). Writing home to his family, Charles describes the comforts of his frontier home, with a "little pine table... covered with... [a] merino cloth...; my flute, my portfolio, and the little pile of books that was always on my table at home... the quilt the girls made...; [and] the curtains Emily hemmed and fringed before my windows" (209). As he creates a comfortable space and shares this space and his books with his neighbors, Charles helps keep the frontier community virtuous, civilized, and middle class.

Emerging at the same time as the phenomenon of mass consumption, as consumer goods became cheaper and available to a larger segment of the population, domestic fiction reflects the anxieties caused by the mass-market revolution, and the underlying question these narratives seek to answer is, quite simply, "What should we buy?" With to-do lists regarding manners, values, and, not least, material possessions for those striving for middle-class status, domestic fiction claims that being middle-class is not primarily about economic assets, but, at the same time, it is implied that middle-class status is established through consumption and that the choice of what to buy actually determines class affiliation. In domestic fiction, the presence of books serves as proof of proper skills of consumption and, thereby, of middle-class status. However, a shelf of books will not only tell visitors that this is a refined middle-class home, the presence of these books, both on the shelf and as instruments of reading, will also help their owners to develop those qualities deemed necessary for middle-class identity as they offer opportunities for intellectual, spiritual, and moral growth. As Charlotte Woodbridge learns, a bookcase in one's home or a book casually lying on a table in the parlor will not only establish social status, it will also help cultivate the minds and moral characters of the inhabitants of this home. This way, books can provide the personal traits necessary to handle the fluctuations of the economy. Once an owner and lover of books, these tales suggest, always a member of the middle class.

\section{BIBLIOGRAPHY}

Works Cited and Consulted 
Amireh, Amal. The Factory Girl and the Seamstress: Imagining Gender and Class in Nineteenth-Century American Fiction. New York: Garland Publishing, 2000. Print.

Ashworth Susanna, "Susan Warner's The Wide, Wide World, Conduct Literature and Protocols of Female Reading in the Mid-Nineteenth Century." Legacy 17:2 (2000), 141-164. Print.

Beecher, Catharine. A Treatise on Domestic Economy. 1841. New York: Schocken Books, 1977. Print. Blumin, Stuart M. The Emergence of the Middle Class: Social Experience and the American City, 1760-1900.Cambridge: Cambridge University Press, 1989. Print.

Brown, Gillian. Domestic Individualism: Imagining Self in Nineteenth-Century America. Berkeley: University of California Press, 1990. Print.

Bushman, Richard L. The Refinement of America: Persons, Houses, Cities. New York: Vintage Books, 1993. Print.

Child, Lydia Maria. The Mother's Book. 1831. Bedford, MA: Applewood Books, 1992. Print.

Crowley, John. The Invention of Comfort: Sensibilities and Design in Early Modern Britain and Early America. Baltimore: Johns Hopkins University Press, 2001. Print.

Damon-Bach, Lucinda, and Victoria Clements. Catharine Maria Sedgwick: Critical Perspectives. Boston: Northeastern University Press, 2003. Print.

Davidson, Cathy. Revolution and the Word: The Rise of the Novel in America. New York: Oxford University Press, 2004. Print.

Downing, Andrew Jackson. Victorian Cottage Residences. 1842. New York: Dover Publications, 1981. Print.

Fichtelberg, Joseph. Critical Fictions: Sentiment and the American Market, 1780-1870. Athens, GA: The University of Georgia Press, 2003. Print.

Foster, Edward Halsey Foster. Susan and Anna Warner. Boston: Twayne Publishers, 1978. Print.

Gallagher, Catherine and Stephen Greenblatt. Practicing New Historicism. Chicago: The University of Chicago Press, 2000. Print.

Grier, Katherine C. Culture and Comfort: Parlor Making and Middle-Class Identity, 1850-1930.

Washington, D.C.: Smithsonian Books, 2010. Print.

Kerber, Linda K. Women of the Republic: Intellect and Ideology in Revolutionary America. New York: W.W. Norton and Company, 1986. Print.

Lang, Amy Schrager. The Syntax of Class: Writing Inequality in Nineteenth-Century America. Ann Arbor: University of Michigan Press, 2006. Print.

Leslie, Eliza. Mr. and Mrs. Woodbridge: A Story of Domestic Life. 1841. Selections from Eliza Leslie. Ed. Etta M. Madden. Lincoln: University of Nebraska Press, 2011. 115-187. Print.

MacFarlane, Lisa Watt. "The New England Kitchen Goes Uptown: Domestic Displacements in Harriet Beecher Stowe's New York.” The New England Quarterly 64:2 (June 1991) 272-291. Print.

Merish, Lori. "'The Hand of Refined Taste' in the Frontier Landscape: Caroline Kirkland's 'A New Home, Who'll Follow' and the Feminization of American Consumerism.” American Quarterly 45:4 (Dec. 1993), 485-523. Print.

---. Sentimental Materialism: Gender, Commodity Culture, and Nineteenth-Century American Literature. Durham: Duke University Press, 2000. Print. 
Robbins, Sarah. Managing Literacy, Mothering America: Women's Narratives on Reading and Writing in the Nineteenth Century. Pittsburgh: The University of Pittsburgh Press, 2004. Print.

Ryan, Mary. Cradle of the Middle Class: The Family in Oneida County, New York, 1790-1865. New York: Cambridge University Press, 1981. Print.

Sedgwick, Catharine Maria. Home. 1835. London: T. Allman, 1850. Print.

---. The Poor Rich Man, and the Rich Poor Man. 1836. Bibliobazaar, 2010. Print.

Shapiro, Joe. "The Providence of Class: Catharine Maria Sedgwick, Political Economy, and Sentimental Fiction in the 1830s." American Literary History 27: 2 (Summer 2015), 199-225. Print.

Sievens, Mary Beth. "Female Consumerism and Household Authority in Early National New England.” Early American Studies (Fall 2006), 353-371. Print.

Silverman, Gillian. Bodies and Books: Reading and the Fantasy of Communion in Nineteenth-Century America. Philadelphia: University of Pennsylvania Press, 2012. Print.

Templin, Mary. Panic Fiction: Women and Antebellum Economic Crisis. Tuscaloosa: The University of Alabama Press, 2014. Print.

Trubey, Elizabeth Fekete. "Imagined Revolution: The Female Reader and The Wide, Wide World." Modern Language Studies 31.2 (Autumn, 2001) 57-74. Print.

Warner, Susan. The Wide, Wide World. 1850. New York: The Feminist Press, 1987. Print.

Zboray, Ronald J., and Mary Saracino Zboray. "Books, Reading, and the World of Goods in Antebellum New England.” American Quarterly 48:4 (Dec. 1996), 587-622. Print.

\section{NOTES}

i. Whereas the significance of owning books has received limited scholarly attention, the act of reading in domestic fiction has been investigated. See for example Robbins, Managing Literacy, Mothering America. The theme of reading has also been explored in The Wide, Wide World, which has received more scholarly attention than the other narratives discussed in this paper. See for example Ashworth and Trubey. Silverman investigates the significance of reading and also the materiality of books in The Wide, Wide World in chapter 5 of Bodies and Books.

ii. Both Fichtelberg and Templin find sentimental fiction, where domestic fiction is a subgenre, to be an arena for discussing the contemporary economic instability. According to Fichtelberg, "[s]entimentalism was called on to mediate the complex and delicate transition between premarket and market mentalities" (7). Focusing on a category of sentimental narratives called "panic fiction," Templin shows that the volatile economy actually created opportunities for female agency.

iii. The relationship between the emerging market society and domestic fiction has been explored by for example Lori Merish, who defines the legacy of domestic fiction as helping to "write into existence a modern consumer psychology, in which individuals 'express themselves' through consumption and 'identify' with personal possessions" (Sentimental Materialism 3) and also claims that "domestic fiction played a key role in the formation and dissemination of capitalist norms of personal life" (6). See also Templin and Lang.

iv. Home is one of Sedgwick's most popular works and went through twenty editions before it went out of print in the year 1900 (Damon-Bach and Clements xxv).

v. Focusing primarily on Mr. Barclay's loss and later reclaim of his childhood home, Merish characterizes the novel as "a phenomenology of sentimental possession... [that] highlights the 
psychological necessity and fragility of an individual's attachments to things and represents property objects as thoroughly interwoven with sentimental subjectivity" (Sentimental Materialism 120).

vi. See also Templin (49-50) for a discussion of this passage.

vii. Exploring social class in The Poor Rich Man and the Rich Poor Man and another Sedgwick novel, Live and Let Live, Joe Shapiro argues that Sedgwick envisions a society where the rich and the poor live in mutual harmony and where the moral character of the rich is established through benevolent acts toward the poor. As a result, Shapiro contends, Sedgwick considered class differences to be socially beneficial.

viii. Silverman offers a different interpretation of Ellen's mother exchanging a ring for a book. She suggests that this exchange shows that Ellen's fate is that of a reader rather than of a romantic heroine, and that, as a result, "Ellen's erotic gaze will be directed more toward books than toward men" (139).

ix. The reason why Ellen's "Bible lust" is portrayed in a positive light has a lot to do with the fact that it is this very book, the Bible, that Ellen craves. The restrictions John Humphrey imposes on Ellen's reading later in the narrative as he makes her promise to "[r]ead no novels" (564) demonstrates that book craving was only desirable for some kinds of books. As many scholars have pointed out, the reading of inappropriate books, such as frivolous novels, was felt to have a deteriorating effect on moral character, especially for young women. See for example Trubey for a discussion of appropriate reading in The Wide, Wide World. In Revolution and the Word, Cathy Davidson explores attitudes to novels in a somewhat earlier time period (chapter 2). Robbins investigates the role of the mother in selecting appropriate reading material for her children, as well as teaching them proper reading practices (see especially chapter 2 ).

To help readers pick which books to buy and read, Home conveniently presents a list of some of the titles in the Barclay bookcase (12) and also mentions the type of books that have been made available for their help, Martha, which shows that what constitutes appropriate reading material depends on the social class of the reader (15).

x. For a discussion of the link between the virtue of Americans, women especially, and the stability and survival of the Republic, see for example Linda K. Kerber, Women of the Republic: Intellect and Ideology in Revolutionary America.

xi. Gillian Brown explores how commodities are rescued from the commercial world by being turned into possessions through sentimental attachment in Stowe's Uncle Tom's Cabin and House and Home Papers (chapter 2, "Sentimental Possession").

xii. The dangers of speculation is a recurring theme in antebellum sentimental fiction and has been investigated by Templin and Fichtelberg, among others.

xiii. Domestic tales, together with advice books, such as Beecher's Treatise, represent some of the efforts made to remedy this deficiency in the education of young middle-class women. Countless fictional and non-fictional works by writers like Catharine Beecher, Lydia Maria Child, Catharine Maria Sedgwick, and Harriet Beecher Stowe offer advice on topics like how to cook and carve meat and the proper way of treating servants, but also on how to make sensible and economical purchases of household goods, such as furniture, food, and dress.

xiv. Another important distinction between the homes of Aunt Fortune and the Humphreys is that whereas the heart of Aunt Fortune's household is the kitchen, the home of the Humphreys center around the parlor. Discussing Harriet Beecher Stowe's novels, Lisa Watt MacFarlane identifies a similar shift between Stowe's historical New England novels and her novels set in New York. While the kitchen is the center of the home in the former works, the parlor has taken its place in the urban New York novels. As MacFarlane points out, this change also reflects a change in the role of the woman in the home since the kitchen figures as a site of production, while the parlor is devoted to consumption. Thus, by relegating the middle-class woman to the parlor, her role becomes one of consumption rather than production (274). The peripheral role of 
the kitchen can also be seen in the floor plans of the houses designed by the contemporary architect and landscape designer A. J. Downing, whose house models were immensely popular among the middle class. These plans generally place a spacious parlor in the front of the house, while the cramped kitchen is situated in the back or even in the basement, with a dumb waiter-a small elevator-bringing up the food to the dining room. This way, oppressive smells from the kitchen would be prevented from spreading throughout the rest of the house and signs of ongoing work were kept away from the reception area of the home.

xv. According to Zboray and Zboray, antebellum publishers realized the economic potential in producing books whose appearance signaled refinement through, for example, their size, binding, and types of print. The focus on appearance, together with the fact that books were advertised as interior decoration (605), demonstrate that the display of books in the home was also a display of social position.

xvi. The importance of books in Ellen's life even takes on an extratextual dimension since after the publication of The Wide, Wide World, Susan Warner and her sister Anna Warner published a series of books called "Ellen Montgomery's Bookshelf," which contained books Ellen was said to like (Foster 74).

xvii. In a similar manner, Bushman notes that "[i]n nineteenth-century usage, comfort was the antidote to aristocratic pretense" (268).

\section{ABSTRACTS}

This paper explores the role of books in American antebellum domestic fiction. Written primarily for middle-class readers, domestic fiction offers advice on how to create an ideal home and in these ideal homes the presence of books is necessary. In an era plagued by a volatile national economy, monetary assets proved an unstable basis for class affiliation. Domestic fiction, however, presents the ownership of books as an alternative foundation for class status. As a result, rather than being based on economic resources, which might lose value overnight, thus causing a plunge on the social ladder, in these tales, middle-class status transcends economic status as it becomes synonymous with the ownership and appreciation of books and the personal qualities books were expected to foster.

\section{INDEX}

Keywords: Eliza Leslie, Catharine Maria Sedgwick, Susan Warner, antebellum consumerism, domestic fiction, domesticity, middle-class ideals, role of book 